\title{
Article \\ European FDI in Ireland and Iceland: Before and after the Financial Crisis
}

\author{
Helga Kristjánsdóttir ${ }^{1, *}$ (i) and Stefanía Óskarsdóttir ${ }^{2}$ (D) \\ 1 Faculty of Business Administration, University of Akureyri, Borgum, Norðurslóð 2, 600 Akureyri, Iceland \\ 2 Faculty of Political Science, University of Iceland, 102 Reykjavík, Iceland; stefosk@hi.is \\ * Correspondence: helga@unak.is
}

check for updates

Citation: Kristjánsdóttir, Helga, and Stefanía Óskarsdóttir. 2021. European FDI in Ireland and Iceland: Before and after the Financial Crisis. Journal of Risk and Financial Management 14:

23. https://doi.org/10.3390/ jrfm14010023

Received: 9 November 2020 Accepted: 25 December 2020 Published: 6 January 2021

Publisher's Note: MDPI stays neutral with regard to jurisdictional clai$\mathrm{ms}$ in published maps and institutional affiliations.

Copyright: () 2021 by the authors. Licensee MDPI, Basel, Switzerland. This article is an open access article distributed under the terms and conditions of the Creative Commons Attribution (CC BY) license (https:// creativecommons.org/licenses/by/ $4.0 /)$.

\begin{abstract}
This paper analyses Foreign Direct Investment (FDI) investment in Ireland and Iceland from other European countries during two periods, i.e., the pre-financial crisis period of 2000-2007 and the financial crisis period of 2008-2010. The aim of this research is to determine what made the countries interesting to foreign investors in both good and bad times; and, secondly, to examine whether European Union membership (and the Euro) made a difference in this respect. The results were obtained by using data from the OECD, the World bank, and other sources. The model constructed for the study applies the inverse hyperbolic sine transformation of the gravity model, which is a novel approach. The results demonstrate that before the financial crisis of 2008, European Union (EU) membership did not help Ireland attract more FDI from other EU countries. However, once it had been hit by the crisis, Ireland attracted more FDI from other EU countries. Iceland, on the other hand, which is not an EU country, attracted FDI from non-EU countries rather than from EU countries before the financial crisis. After the crisis, however, the origin within Europe, of FDI in Iceland had no significant effect on the flow of FDI into the country.
\end{abstract}

Keywords: European Union (EU); Foreign Direct Investment FDI; Trade Blocs; EFTA; International Monetary Fund (IMF)

\section{Introduction}

This paper analyses Foreign Direct Investment (FDI) investment in Ireland and Iceland from other European countries during two periods, i.e., the pre-financial crisis period of 2000-2007 and the financial crisis period of 2008-2010. The aim of this research is to determine what made the countries interesting to investors in both good and bad times; and, secondly, to examine whether European Union (EU) membership (and the Euro) made a difference in this respect. Before deciding whether to invest long term in another country, investors take various economic and political factors into consideration. In this paper we look at some of these factors to see which mattered the most. They include the risk of political instability, government efficiency, country endowments, country credit rating, investment risk, cultural distance and trade-bloc membership. The recent exit of Britain from the European Union (EU 2020), Euro skepticism in various parts of Europe, as well as the recent economic downturn in Europe due to Covid-19, indicate that there are lessons to be learnt from this research for other small and medium sized economies. Data on FDI from the OECD (2020) was used for the analysis.

Before explaining in further details the design of the study, the data and the results, a few words are warranted to explain why comparing Ireland and Iceland is interesting. Although Ireland and Iceland have some things in common, they also differ in some ways (EU 2020; EFTA 2020). The greatest political-economic difference between the two countries is that Ireland belongs to the EU and has adopted the Euro while Iceland has not. Both countries are small island states with open economies (World Bank 2020). Of the two, Iceland has a much smaller population than Ireland, some 360.000 compared to Ireland's 
almost five million inhabitants (World Bank 2020). Both countries have a relatively welleducated labor force and good living standards (World Bank 2020; OECD 2020). Thus in 2007 the GDP per capita in Iceland was $€ 50,500$ compared to $€ 44,820$ in Ireland (IMF 2020). Additionally, being small open economies both countries depend heavily on exports and imports (Krugman 1991). As a result, trade is very important for both countries. However, as has already been pointed out, they have taken different paths when it comes to memberships in trade alliances (EU 2020; EFTA 2020).

Ireland was one of the founding members of the European Free Trade Agreement (EFTA), established in 1960. In 1973 Ireland joined the European Community (EC) along with Britain and Denmark, which in 1993 became the European Union (EU). Iceland, on the other hand, joined the EFTA in 1970 (EFTA 2020). In 1994 the remaining EFTA countries (Iceland, Norway and Lichtenstein) and the EU established the European Economic Area (EEA) which secures the free movement of goods, capital, labor, and services within the European single market, although with some exceptions (EU 2020). For example, in the case of Iceland, foreign ownership of companies in the, locally important, fishing sector cannot exceed $49 \%$.

When the Euro came into existence in 1999, many of the EU countries adopted it as their currency, including Ireland. In comparison, Iceland kept its small currency (Króna, ISK) and remained outside the EU. By not joining the EU, Iceland stayed out of the EU's Common Fisheries Policy, the Common Agricultural Policy, as well as the major EU institutions. By keeping its currency, Iceland retained full control over its monetary policy. Since 2002 the value of the Icelandic Króna (ISK) has been determined by the forces of supply and demand (floating currency), managed by the Icelandic Central Bank (ECB 2020), which enjoys autonomy from the government.

In the years leading up to the financial crisis of 2008, both Iceland and Ireland saw high inflows of foreign capital and investment (World Bank 2020; IMD 2020; Kristjánsdóttir 2010; Markusen 2004). In the case of Iceland, high domestic interest rates and cheap foreign loans had contributed to some of this inflow. However, once concerns grew about the viability of the Icelandic banking system, capital flight began (IMF 2020; OECD 2020). With a shrinking supply of foreign currencies, coupled with a great demand for them, the value of the ISK dropped by some $50 \%$ in 2008 . The Icelandic state also proved unable to save its major banks, which then filed for bankruptcies in October 2008. The resulting economic crisis directly impacted firms as well as the public, fueling political unrest as well (e.g., Benediktsdóttir et al. 2011; Óskarsdóttir 2013). Iceland entered an IMF program in 2008 (Gissurarson 2010; IMF 2018). In contrast, Ireland, as a member of the Euro-zone, was able to get help from its European allies with re-financing its banks, thus saving them from a collapse. However, in turn, its public debt rose rapidly as did unemployment due to the impact of the financial crisis (e.g., Riain 2012; OECD 2020).In Iceland, the currency crisis contributed to the decision of the Icelandic government to apply for EU membership in 2009, with the aim of joining the Euro-zone (ECB 2020). For a few years, the question of EU membership dominated the political discourse in Iceland (e.g., Thorhallsson and Rebhan 2011). However, a new government coalition that came into power in 2013, decided to withdraw the EU application, with the argument that it best served Iceland's interests to remain outside of the EU and not adopting the Euro (Guardian 2015).

As the results will show, this might have been the right call. Before the financial crisis of 2008, EU membership did not help Ireland attract more FDI from other EU countries. However, once the crisis had hit Ireland, EU membership seems to have made a difference in that it attracted FDI from other EU countries. Iceland, on the other hand, attracted FDI from non-EU countries rather than EU countries before the financial crisis. After the crisis, however, the origin within Europe, of FDI in Iceland had no significant effect on the flow of FDI into the country.

The paper is structured as follows. Section 2 lays out the literature review as it relates to FDI within international economics. Section 3 provides description of the model specifications of the gravity model used in this study, in order to best capture determinants of 
FDI in Iceland and Ireland, before and after the global financial crisis. Section 4 offers a description of the data applied in this current research. Section 5 presents the regression results, obtained from estimating various gravity model specifications, running before and after the financial crisis. Finally, Section 5 provides a summary and conclusions. The findings indicate that the EU membership of Ireland was not beneficial in attracting FDI from European countries before the financial crisis. However, it had positive significant effects on FDI inflow after the crisis. Additionally, an EU membership of European countries had a significant negative impact on their incentive to undertake FDI in Iceland before the crisis, and insignificant effects after the crisis.

\section{Literature Review}

Newton presented the gravity model within the field of physics. According to it, the gravity force is subject to two masses and how distant they are from each other (Keesing 1998). Economists have applied the gravity model successfully in economics, when estimating the determinants of trade in the form of exports and FDI (Markusen 2004). Interesting presentations of the gravity model were made by Tinbergen (1962) and Pöyhönen (1963).

Helpman (1984) introduced the vertical model of FDI and Markusen (1984) the horizontal model, accounting for vertical FDI and horizontal FDI. Bergstrand (1985) also provided a theoretical basis for the gravity model and Krugman (1991) allowed for increasing returns and economic geography. Krugman (2011) explained that smaller economies tend to be less diversified and rely on few main industries. Growing research has been published within international economics on foreign direct investment (e.g., Carr et al. 2001; Markusen 2004). Features of both the vertical and horizontal models are accounted for in a research by Markusen et al. (1996). This is also well documented in Markusen (2004).

Several studies have studied the determinants of foreign direct investment (Davies and Kristjánsdóttir 2010; Davies et al. 2008). Some have looked on FDI determinants in general (Davies 2008) and other specifically on islands like Iceland (Kristjánsdóttir 2013). Studies have sought to analyze factors like culture and FDI (Hofstede 1980, 2001; Kristjánsdóttir 2010, 2012, 2013, 2016a, 2016b, 2017, 2019a, 2019b, 2020; Kristjánsdóttir et al. $2017,2020)$. Research has also shown that numerous variables are significant when it comes to estimating trade flows, foreign direct investment and return on investment (Markusen 2004; Kristjánsdóttir 2010, 2012, 2013, 2016a, 2016b, 2017, 2019a, 2019b, 2020; Kristjánsdóttir and Óskarsdóttir 2020; Kristjánsdóttir and Kristjánsdóttir 2021).

We seek to determine how FDI is affected like issues like GMT government efficiency (Kristjánsdóttir 2016b). The data approach is like the one used by Davies (2008). We apply the Gravity model as presented by Bergstrand (1985) and skill differences as presented in the knowledge capital model (Carr et al. 2001). Along the lines of (Zwinkels and Beugelsdijk 2010), we account for risk of political instability, government efficiency, country credit rating, and investment risk. Moreover, we account for culture based on the Hofstede culture measure (Hofstede 1980, 2001; Hofstede and Bond 1988; Kristjánsdóttir et al. 2017, 2020). Such an approach makes it possible to estimate important determinants of FDI (Markusen 2004) in small open economies (Kristjánsdóttir 2020).

The contribution of this study, within in the field of international economics, is to use both economic and political variables. Because it is important not only to look at economic factors, but also at political factors as well. Usually, studies on FDI are focused on basic economic factors, but this research incorporates risk, credit rating, political instability, and government efficiency.

\section{Model Specification}

The choice of method in this research is based on Krugman's increasing returns and economic geography (Krugman 1991), linking economic weight with distance in the gravity model setting. Thus, the method involves usage of the gravity model (Bergstrand 1985; Carr et al. 2001) which is suitable, comparing determinant factors of FDI such as 
economic size (GDP) market size (POP) cultural distance (Hofstede), skill differences, and EU membership. Our additional theoretical contribution is application of the inverse hyperbolic sine transformation of the gravity model (Kristjánsdóttir 2012). Conventionally, the logarithm serves well in in the gravity model specification. Use of the inverse hyperbolic sine transformation rather than the logarithm transformation allows for accountancy of zeros, which can be important in the study of small economies with limited databases (Kristjánsdóttir 2012). The gravity model specification used in this study is based on the specification by Bergstrand (1985) in Equation (1). In Equation (1) PX is exports from country $i$ to $j$, and $Y i$ represents GDP in country $i$, and $Y_{j}$ represents GDP in country $j, A$ accounts for additional factors, and the error term is $u$.

$$
P X_{i j}=\beta_{0}\left(Y_{j}\right)^{\beta_{1}}\left(Y_{j}\right)^{\beta_{2}}\left(D_{i j}\right)^{\beta_{3}}\left(A_{i j}\right)^{\beta_{4}} u_{i j}
$$

Equation (2) represents exports (EXP) as the dependent variable, from country $i$ to country $j$, over time $t$.

$$
\operatorname{EXP}_{i j, t}=e^{\gamma_{0}}\left(Y_{i, t}\right)^{\gamma_{1}}\left(Y_{j, t}\right)^{\gamma_{2}}\left(D_{i j}\right)^{\gamma_{3}}\left(A_{i j}\right)^{\gamma_{4}} e^{\zeta_{i j, t}}
$$

Equation (3) represents the model specification, when GDP has been inserted for $Y$, $D I S$ distance for $D$, and POP population for $A$.

$$
E X P_{i j, t}=e^{\varsigma_{0}}\left(G D P_{i, t}\right)^{\varsigma_{1}}\left(G D P_{j, t}\right)^{\varsigma_{2}}\left(P O P_{i, t}\right)^{\varsigma_{3}}\left(P O P_{j, t}\right)^{\varsigma_{4}}\left(D I S_{i j}\right)^{\varsigma_{5}} e^{\lambda_{i j, t}}
$$

Equation (4) presents the model specification, after taking logarithm of all variables. Equation (4) therefore presents the log-linear format of the specification.

$$
\ln \left(E X P_{i j, t}\right)=\varsigma_{0}+\varsigma_{1} \ln \left(G D P_{i, t}\right)+\varsigma_{2} \ln \left(G D P_{j, t}\right)+\varsigma_{3} \ln \left(P O P_{i, t}\right)+\varsigma_{4} \ln \left(P O P_{j, t}\right)+\varsigma_{5} \ln \left(D I S_{i j}\right)+u_{i j, t}
$$

\begin{tabular}{|c|c|}
\hline FDI stock $i j, t$ & $\begin{array}{l}\text { FDI series of BOP and IIP aggregates. Inward position at year-end US dollar, } \\
\text { millions in host country }(j) \text {, over time }(t) \text {. OECD }(2020) \text {. }\end{array}$ \\
\hline$G D P_{i, t}$ & $\begin{array}{l}\text { Gross domestic product (GDP) current US\$, in host country }(j) \text {. Running over time } \\
(t) \text {. World Bank (2020). }\end{array}$ \\
\hline$P O P_{i, t}$ & Population, in source country $(i)$ at time $(t)$. IMD (2020). \\
\hline $\operatorname{SDiff}_{i j, t}$ & $\begin{array}{l}\text { Difference in the availability of skilled labor, between source country }(i) \text { and host } \\
\text { country }(j) \text { over time }(t) \text {. IMD (2020). }\end{array}$ \\
\hline$E U_{i, t}$ & $\begin{array}{l}\text { Dummy variable accounting for the source country }(i) \text { membership to the } \\
\text { European Union, over time }(t) \text {. European Union (EU 2020). }\end{array}$ \\
\hline HOFSTEDE $_{i}$ & $\begin{array}{l}\text { Hofstede cultural distance index of the source country }(i) \text {. Aðalsteinsson et al. } \\
\text { (2011). Hofstede and Bond (1988); Hofstede }(1980,2001) \text {. }\end{array}$ \\
\hline CREDIT $_{j, t}$ & The country credit rating, in the host country $(j)$, over time $(t)$. IMD (2020). \\
\hline$R I S K_{j, t}$ & Investment risk, in the host country $(j)$, over time $(t)$. IMD (2020). \\
\hline$I_{N S T} T_{j, t}$ & $\begin{array}{l}\text { The risk of political instability is very low, in the host country }(i) \text {, over time }(t) \text {. } \\
\text { IMD (2020). }\end{array}$ \\
\hline$G M T_{j, t}$ & $\begin{array}{l}\text { Government efficiency, government decisions are effectively implemented, in the } \\
\text { host country }(j) \text {, over time }(t) \text {. IMD (2020). }\end{array}$ \\
\hline
\end{tabular}

Table 1 shows the variables used in the study, and summary statistics are presented in Table 2.

Table 1. Variable Definition. 
Table 2. Summary Statistics for the Basic Sample.

\begin{tabular}{|c|c|c|c|c|c|}
\hline Variable & Units & Mean & Std. Dev. & Min & Max \\
\hline$F D I_{i j, t}$ Iceland & USD & 187.7572 & 982.4527 & -6.164 & 9538.254 \\
\hline$F D I_{i j, t}$ Ireland & US dollars & 132.8809 & 3273.049 & -24652.05 & 20777.55 \\
\hline$G D P_{i, t}$ & US dollars & $8.56 \times 10^{11}$ & $1.82 \times 10^{12}$ & $3.78 \times 10^{9}$ & $1.51 \times 10^{13}$ \\
\hline$P O P_{i, t}$ & Inhabitants & 103.9129 & 260.2633 & 0.279 & 1344.002 \\
\hline Skills $_{i, t}$ & Index $[0,10]$ & 5.955366 & 1.313986 & 0 & 8.380953 \\
\hline$E U_{i, t}$ & $E U_{i, t} \in\{0,1\}$ & 0.3965116 & 0.4894576 & 0 & 1 \\
\hline HOFSTEDE $E_{i}$ & Index $[0,100]$ & 49.95874 & 8.732228 & 29.63903 & 66.84524 \\
\hline$I_{c e} C \mathrm{CREDIT} \mathrm{T}_{\mathrm{j}, t}$ & Index $[0,10]$ & 70.68182 & 12.4131 & 41 & 80.8 \\
\hline$I_{c e}{ }_{2} R I S K_{j, t}$ & Index $[0,10]$ & 84.10378 & 9.946038 & 64.39 & 92.13 \\
\hline$I_{c e} I N S T_{j, t}$ & Index $[0,10]$ & 7.143074 & 3.09788 & 0 & 9.302325 \\
\hline$I c e \_G M T_{j, t}$ & Index $[0,10]$ & 5.359459 & 2.281748 & 0 & 7.069767 \\
\hline Ire_CREDIT $_{j, t}$ & Index $[0,10]$ & 86.81818 & 7.189874 & 67.5 & 93.2 \\
\hline$I_{r e \_R I S K}^{j, t}$ & Index $[0,10]$ & 90.27111 & 5.384146 & 77.87 & 94.65 \\
\hline Ire_INST $_{j, t}$ & Index $[0,10]$ & 8.779427 & 0.9121318 & 6.32653 & 9.568627 \\
\hline Ire_GMT $T_{j, t}$ & Index $[0,10]$ & 5.123729 & 0.865086 & 3.772727 & 6.533333 \\
\hline
\end{tabular}

The equations estimates are based on the gravity model (Markusen 2004), these are the following;

$$
\begin{aligned}
& \sinh ^{-1}\left(F I_{i j, t}\right)= \tau_{0}+\tau_{1} \ln \left(G D P_{i, t}\right)+\tau_{2} \ln \left(\text { POP }_{i, t}\right)+\tau_{3} \text { SDiff }_{i j, t} \\
&+\tau_{4} \text { EU }_{i, t}+\tau_{5} \text { HOFSTEDE } \\
& i
\end{aligned}
$$

In Equation (5) Foreign Direct Investment (FDI) is the dependent variable. FDI is treated with the inverse hyperbolic sine function $\left(\sinh ^{-1}\right)$ in order to take zeros and potential negative values into account. Then the explanatory variables are the conventional gravity model variables of gross domestic product $(G D P)$ and market size with population $(P O P)$. Then SDiff accounts for skill differences between the source country of investment, and the host country. $E U$ is a dummy variable for the European Union, taking the value 1 if the source country has EU membership and 0 if not. The HOFSTEDE variable accounts for cultural value of the source country of investment and Credit the Credit status in the host country of investment.

Then the regressions continue and next the RISK replaces the CREDIT variable, as presented in Equation (6):

$$
\begin{aligned}
\sinh ^{-1}\left(F D I_{i j, t}\right)= & \tau_{0}+\tau_{1} \ln \left(G D P_{i, t}\right)+\tau_{2} \ln \left(\text { POP }_{i, t}\right)+\tau_{3} \text { SDiff }_{i j, t} \\
& +\tau_{4} E U_{i, t}+\tau_{5} \text { HOFSTEDE }_{i}+\tau_{6} \text { RISK }_{j, t}+\varepsilon_{i j, t}
\end{aligned}
$$

Equation (6) continues with FDI, GDP, POP and from the Knowledge Capital model there is the SDiff variable (Carr et al. 2001; Markusen 2004). Furthermore, by replacing RISK with the INST variable, the regression accounts for risk in the host country.

$$
\begin{aligned}
\sinh ^{-1}\left(F D I_{i j, t}\right)= & \tau_{0}+\tau_{1} \ln \left(G D P_{i, t}\right)+\tau_{2} \ln \left(P O P_{i, t}\right)+\tau_{3} S D i f f_{i j, t} \\
& +\tau_{4} E U_{i, t}+\tau_{5} \text { HOFSTEDE } E_{i}+\tau_{6} I_{N S T} T_{j, t}+\varepsilon_{i j, t}
\end{aligned}
$$


In Equation (7) the INST variable accounts for risk of political instability in the host country of investment.

$$
\begin{aligned}
\sinh ^{-1}\left(F D I_{i j, t}\right)= & \tau_{0}+\tau_{1} \ln \left(G D P_{i, t}\right)+\tau_{2} \ln \left(P_{0} P_{i, t}\right)+\tau_{3} \text { SDiff }_{i j, t} \\
& +\tau_{4} \text { EU }_{i, t}+\tau_{5} \text { HOFSTEDE } \\
&
\end{aligned}
$$

Finally, we estimate equation with the GMT government efficiency variable in Equation (8). Then government efficiency (GMT) replaces RISK, with government efficiency accounting for the government efficiency in the source country of investment.

\section{Data}

A total of 25 European countries are included in the set of data, these are: Austria, Belgium, Czech Republic, Denmark, Estonia, Finland, France, Germany, Greece, Hungary, Iceland, Ireland, Israel, Italy, Luxembourg, Netherlands, Norway, Poland, Portugal, Slovak Republic, Slovenia, Spain, Sweden, Switzerland, and the United Kingdom. Data is on annual bases, reporting values for every year. We use dataset obtained from the OECD. "The Organization for Economic Co-operation and Development is an intergovernmental economic organization, founded in 1961 to stimulate economic progress and world trade" (OECD 2020). Economists have used OECD dataset to analyze the determinants of FDI (Kristjánsdóttir 2016a, 2016b). FDI stock $_{j, t}$ is the FDI series of BOP and IIP aggregates. Inward position at year-end US dollar, millions in host country $(j)$, over time $(t)$, obtained from the OECD (2020).

$G D P_{i, t}$ is the gross domestic product (GDP) current US\$, in host country (i). Running over time $(t)$, obtained from World Bank (2020). $P O P_{i, t}$ is population, obtained from IMD (2020). SDiff $i j, t$ the difference in the availability of skilled labor, between source country and host country of investment, obtained from IMD (2020). $E U_{i, t}$ is the dummy variable accounting for the source country membership to the European Union, over time $(t)$, obtained from ECB (2020).

HOFSTEDE $E_{i}$ is the Hofstede (2001) cultural distance index of the source country, obtained from Hofstede (1980, 2001), Hofstede and Bond (1988), Aðalsteinsson et al. (2011). Data on the Hofstede culture variable captures cultural effects (Hofstede 1980, 2001; Hofstede and Bond 1988; Kristjánsdóttir et al. 2017, 2020). The most common version of the Hofstede index does not include data on Iceland. We therefore add data for Iceland obtained by Aðalsteinsson et al. (2011), applying the same questionnaire and data processing as Hofstede.

The Hofstede measures occasionally take a value over 100 for the sample countries. We therefore rescale values, so they take a maximum value of 100 . Then the five measures are summed up, and divided by 100 again, so the overall Hofstede index used here runs from 0 to 100 . CREDIT $j, t$ is the country credit rating, in the host country, obtained from the IMD (2020). The country credit rating variable CREDIT accounts for rating on a scale of 0-100 assessed by the Institutional Investor IMD (2020). Before application, the CREDIT variable is such that we divide all values by 10 , and it therefore runs from zero to 10 .

$R I S K_{j, t}$ is investment risk, in the host country, obtained from the IMD (2020). The investment RISK variable measures the Euromoney country risk overall (scale from 0-100) and is obtained from the IMD (2020). The RISK variable is divided by 10, so it runs from 0-10.

$I N S T_{j, t}$ is the risk of political instability is very low, in the host country, obtained from the IMD (2020). The variable INST data is from an executive survey based on an index from zero to 10 IMD International in Lausanne Switzerland, collects indicators for various factors, including infrastructure (IMD 2020).

$G M T_{j, t}$ is the government efficiency, government decisions are effectively implemented, in the host country, obtained from the IMD (2020). The GMT variable from an executive survey based on an index from zero to ten (IMD 2020).

The number of documents analysed is reflected in the reference list, listing 40 references, including both data files and theoretical documents. The software used is the STATA software. The data analysis method involves use of the gravity model, accounting for economic size 
and distance, which is particularly useful when considering countries with small economy size, like Iceland and Ireland, geographically distant from the centre of Europe.

\section{Regression Results}

The analyzed period runs in two subperiods, the first subperiod runs from 2000-2007 and the second subperiod from 2008-2010. The regressions are run on these two different subperiods in order to get estimates on the determinants of foreign direct investment (FDI), before and after the global financial crisis.

Results are obtained by using the Ordinary least squares (OLS) regression. When reading through Tables 3-6, the estimation results can be interpreted as the following:

Table 3. 2000-2007 ICELAND.

\begin{tabular}{|c|c|c|c|c|}
\hline & Equation (5) & Equation (6) & Equation (7) & Equation (8) \\
\hline Regressors & FDI Stock $k_{i j, t}$ & FDI Stock $k_{i j, t}$ & FDI Stock $k_{i j, t}$ & FDI Stock ${ }_{i j, t}$ \\
\hline$G D P_{i, t}$ & $\begin{array}{c}1.426^{* * *} \\
(9.40)\end{array}$ & $\begin{array}{c}1.506^{* * *} \\
(8.08)\end{array}$ & $\begin{array}{c}1.436^{* * *} \\
(8.86)\end{array}$ & $\begin{array}{c}1.429 * * * \\
(9.20)\end{array}$ \\
\hline$P O P_{i, t}$ & $\begin{array}{c}-0.855^{* *} \\
(-7.56)\end{array}$ & $\begin{array}{c}-0.849^{* * *} \\
(-6.89)\end{array}$ & $\begin{array}{c}-0.860 * * * \\
(-7.33)\end{array}$ & $\begin{array}{c}-0.857 * * * \\
(-7.48)\end{array}$ \\
\hline$S \operatorname{Diff} f_{i j, t}$ & $\begin{array}{l}0.193 \\
(1.05)\end{array}$ & $\begin{array}{c}0.452 * * * \\
(2.78)\end{array}$ & $\begin{array}{l}0.193 \\
(1.06) \\
\end{array}$ & $\begin{array}{l}0.191 \\
(1.05) \\
\end{array}$ \\
\hline$E U_{i, t}$ & $\begin{array}{c}-0.981^{* * *} \\
(-3.30)\end{array}$ & $\begin{array}{l}-0.673 * \\
(-1.94)\end{array}$ & $\begin{array}{c}-0.980^{* * *} \\
(-3.25)\end{array}$ & $\begin{array}{c}-0.981^{* * *} \\
(-3.26)\end{array}$ \\
\hline HOFSTEDE ${ }_{i}$ & $\begin{array}{c}-0.128^{* * *} \\
(-8.63)\end{array}$ & $\begin{array}{c}-0.140 * * * \\
(-8.42)\end{array}$ & $\begin{array}{c}-0.129^{* * *} \\
(-8.87)\end{array}$ & $\begin{array}{c}-0.128^{* * *} \\
(-8.88)\end{array}$ \\
\hline$I_{c e} \_C R E D I T_{j, t}$ & $\begin{array}{l}-0.002 \\
(-0.07)\end{array}$ & & & \\
\hline$I_{c e} \_R I S K_{j, t}$ & & $\begin{array}{l}0.029 \\
(0.28) \\
\end{array}$ & & \\
\hline$I c e \_I N S T_{j, t}$ & & & $\begin{array}{l}0.190 \\
(0.31)\end{array}$ & \\
\hline$I_{c e} G M T_{j, t}$ & & & & $\begin{array}{l}0.122 \\
(0.32)\end{array}$ \\
\hline Constant & $\begin{array}{c}-26.693^{* * * *} \\
(-5.31)\end{array}$ & $\begin{array}{c}-31.046^{* * *} \\
(-2.80)\end{array}$ & $\begin{array}{c}-28.796^{* * *} \\
(-3.79)\end{array}$ & $\begin{array}{c}-27.759 \text { *** } \\
(-6.15)\end{array}$ \\
\hline R-sq & 0.4666 & 0.4908 & 0.4669 & 0.4669 \\
\hline Obs & 172 & 131 & 172 & 172 \\
\hline
\end{tabular}

Robust t-statistics reported in parentheses. ${ }^{* * *}$ Significant at the 1 percent level. ${ }^{* *}$ Significant at the 5 percent level. * Significant at the 10 percent level.

Table 4. 2008-2010 ICELAND.

\begin{tabular}{ccccc}
\hline & Equation (5) & Equation (6) & Equation (7) $^{\text {Equation (8) }}$ \\
\hline Regressors & FDI Stock $_{i j, t}$ & FDI Stock $_{i j, t}$ & FDI Stock $_{i j, t}$ & FDI Stock $_{i j, t}$ \\
\hline \multirow{2}{*}{$G D P_{i, t}$} & $1.359^{* * *}$ & $1.361^{* * *}$ & $1.359^{* * *}$ & $1.357^{* * *}$ \\
& $(4.90)$ & $(4.91)$ & $(4.91)$ & $(4.91)$ \\
\hline \multirow{2}{*}{$P O P_{i, t}$} & $-0.926^{* * *}$ & $-0.927^{* * *}$ & $-0.926^{* * *}$ & $-0.924^{* * *}$ \\
& $(-4.67)$ & $(-4.68)$ & $(-4.70)$ & $(-4.71)$ \\
\hline \multirow{2}{*}{$S D i f f_{i j, t}$} & 0.006 & 0.001 & -0.001 & 0.002 \\
& $(0.10)$ & $(0.02)$ & $(-0.01)$ & $(0.03)$ \\
\hline
\end{tabular}


Table 4. Cont.

\begin{tabular}{|c|c|c|c|c|}
\hline & Equation (5) & Equation (6) & Equation (7) & Equation (8) \\
\hline$E U_{i, t}$ & $\begin{array}{l}-0.437 \\
(-0.95)\end{array}$ & $\begin{array}{l}-0.435 \\
(-0.94)\end{array}$ & $\begin{array}{l}-0.434 \\
(-0.94)\end{array}$ & $\begin{array}{l}-0.435 \\
(-0.94)\end{array}$ \\
\hline HOFSTEDE $E_{i}$ & $\begin{array}{c}-0.130 * * * \\
(-5.89)\end{array}$ & $\begin{array}{c}-0.130 * * * \\
(-5.90)\end{array}$ & $\begin{array}{c}-0.130 * * * \\
(-5.91)\end{array}$ & $\begin{array}{c}-0.130^{* * *} \\
(-5.91)\end{array}$ \\
\hline$I_{c e} C R E D I T_{j, t}$ & $\begin{array}{l}-0.012 \\
(-0.77)\end{array}$ & & & \\
\hline$I_{c e}{ }_{2} R I S K_{j, t}$ & & $\begin{array}{l}-0.016 \\
(-0.68)\end{array}$ & & \\
\hline$I_{c e} I N S T_{j, t}$ & & & $\begin{array}{l}-0.029 \\
(-0.35)\end{array}$ & \\
\hline$I_{c e}{ }_{G M T} T_{j, t}$ & & & & $\begin{array}{l}-0.032 \\
(-0.26)\end{array}$ \\
\hline constant & $\begin{array}{c}-25.041 \text { ** } \\
(-3.54)\end{array}$ & $\begin{array}{c}-24.559 * * \\
(-3.40)\end{array}$ & $\begin{array}{c}-25.605^{* * *} \\
(-3.68)\end{array}$ & $\begin{array}{c}-25.560^{* * *} \\
(-3.68)\end{array}$ \\
\hline R-sq & 0.4251 & 0.4241 & 0.4217 & 0.4213 \\
\hline Obs & 87 & 87 & 87 & 87 \\
\hline
\end{tabular}

Robust t-statistics reported in parentheses. ${ }^{* * *}$ Significant at the 1 percent level. ${ }^{* *}$ Significant at the 5 percent level.

Table 5. 2000-2007 IRELAND.

\begin{tabular}{|c|c|c|c|c|}
\hline & Equation (5) & Equation (6) & Equation (7) & Equation (8) \\
\hline Regressors & FDI Stock $k_{i j, t}$ & FDI Stock $k_{i j, t}$ & FDI Stock $k_{i j, t}$ & FDI Stock $k_{i j, t}$ \\
\hline$G D P_{i, t}$ & $\begin{array}{l}0.386 \\
(0.61)\end{array}$ & $\begin{array}{l}0.122 \\
(0.19)\end{array}$ & $\begin{array}{l}0.431 \\
(0.66)\end{array}$ & $\begin{array}{l}0.247 \\
(0.40)\end{array}$ \\
\hline$P O P_{i, t}$ & $\begin{array}{l}-0.553 \\
(-1.12)\end{array}$ & $\begin{array}{l}-0.389 \\
(-0.80)\end{array}$ & $\begin{array}{l}-0.555 \\
(-1.10)\end{array}$ & $\begin{array}{l}-0.419 \\
(-0.87)\end{array}$ \\
\hline$S \operatorname{Diff} f_{i j, t}$ & $\begin{array}{l}-0.476 \\
(-1.01) \\
\end{array}$ & $\begin{array}{l}-0.391 \\
(-0.85) \\
\end{array}$ & $\begin{array}{l}-0.373 \\
(-0.81)\end{array}$ & $\begin{array}{l}-0.295 \\
(-0.64) \\
\end{array}$ \\
\hline$E U_{i, t}$ & $\begin{array}{l}-0.388 \\
(-0.37)\end{array}$ & $\begin{array}{l}-0.981 \\
(-0.91) \\
\end{array}$ & $\begin{array}{l}-0.359 \\
(-0.34)\end{array}$ & $\begin{array}{l}-0.464 \\
(-0.43)\end{array}$ \\
\hline$H_{O F S T E D E}$ & $\begin{array}{l}-0.018 \\
(-0.29)\end{array}$ & $\begin{array}{l}-0.030 \\
(-0.48)\end{array}$ & $\begin{array}{l}-0.016 \\
(-0.26)\end{array}$ & $\begin{array}{l}-0.018 \\
(-0.29)\end{array}$ \\
\hline Ire_CREDIT $T_{j, t}$ & $\begin{array}{c}-0.466 \text { ** } \\
(-2.30)\end{array}$ & & & \\
\hline Ire_RISK $K_{j, t}$ & & $\begin{array}{c}0.21 \\
(0.36)\end{array}$ & & \\
\hline$I_{r} e_{-} I N S T_{j, t}$ & & & $\begin{array}{c}-8.673^{* *} \\
(-2.31)\end{array}$ & \\
\hline Ire_GMT $T_{j, t}$ & & & & $\begin{array}{l}0.745 \\
(0.79)\end{array}$ \\
\hline constant & $\begin{array}{c}34.632 \\
(1.50)\end{array}$ & $\begin{array}{l}-19.718 \\
(-0.36)\end{array}$ & $\begin{array}{c}72.096^{* *} \\
(1.98)\end{array}$ & $\begin{array}{l}-8.043 \\
(-0.45)\end{array}$ \\
\hline $\mathrm{R}-\mathrm{sq}$ & 0.0368 & 0.0146 & 0.0408 & 0.0093 \\
\hline Obs & 168 & 160 & 168 & 168 \\
\hline
\end{tabular}

Robust t-statistics reported in parentheses. ** Significant at the 5 percent level. 
Table 6. 2008-2010 IRELAND.

\begin{tabular}{|c|c|c|c|c|}
\hline & Equation (5) & Equation (6) & Equation (7) & Equation (8) \\
\hline Regressors & FDI Stock $_{i j, t}$ & FDI Stock $_{i j, t}$ & FDI Stock $_{i j, t}$ & FDI Stock $_{i j, t}$ \\
\hline$G D P_{i, t}$ & $\begin{array}{l}1.691 \\
(1.59)\end{array}$ & $\begin{array}{l}1.688 \\
(1.59)\end{array}$ & $\begin{array}{l}1.700 \\
(1.62)\end{array}$ & $\begin{array}{l}1.688 \\
(1.59)\end{array}$ \\
\hline$P O P_{i, t}$ & $\begin{array}{c}-1.619 * * \\
(-2.07)\end{array}$ & $\begin{array}{c}-1.618^{* *} \\
(-2.07)\end{array}$ & $\begin{array}{c}-1.615^{* *} \\
(-2.10)\end{array}$ & $\begin{array}{c}-1.617^{* *} \\
(-2.07)\end{array}$ \\
\hline $\operatorname{SDiff}_{i j, t}$ & $\begin{array}{l}-0.768 \\
(-1.43)\end{array}$ & $\begin{array}{l}-0.756 \\
(-1.39) \\
\end{array}$ & $\begin{array}{l}-0.739 \\
(-1.27)\end{array}$ & $\begin{array}{l}-0.7514 \\
(-1.38)\end{array}$ \\
\hline$E U_{i, t}$ & $\begin{array}{c}3.586 \text { ** } \\
(2.17)\end{array}$ & $\begin{array}{c}3.577 * * \\
(2.16)\end{array}$ & $\begin{array}{c}3.576^{* *} \\
(2.14)\end{array}$ & $\begin{array}{c}3.574^{* *} \\
(2.16)\end{array}$ \\
\hline HOFSTEDE $E_{i}$ & $\begin{array}{l}0.087 \\
(0.89)\end{array}$ & $\begin{array}{l}0.087 \\
(0.89)\end{array}$ & $\begin{array}{l}0.084 \\
(0.88)\end{array}$ & $\begin{array}{l}0.087 \\
(0.89)\end{array}$ \\
\hline$I_{r e} C R E D I T_{j, t}$ & $\begin{array}{l}-0.030 \\
(-0.39)\end{array}$ & & & \\
\hline$I_{r e \_R I S K} K_{j, t}$ & & $\begin{array}{l}-0.050 \\
(-0.39)\end{array}$ & & \\
\hline$I_{r e \_I N S T} T_{j, t}$ & & & $\begin{array}{l}-0.414 \\
(-0.26)\end{array}$ & \\
\hline Ire_GMT $T_{j, t}$ & & & & $\begin{array}{l}-0.706 \\
(-0.38)\end{array}$ \\
\hline constant & $\begin{array}{c}-44.499 \\
(-1.52)\end{array}$ & $\begin{array}{c}-42.587 \\
(-1.37)\end{array}$ & $\begin{array}{c}-43.649 \\
(-1.38)\end{array}$ & $\begin{array}{l}-43.812 \\
(-1.47)\end{array}$ \\
\hline $\mathrm{R}-\mathrm{sq}$ & 0.1280 & 0.1280 & 0.1269 & 0.1280 \\
\hline Obs & 77 & 77 & 77 & 77 \\
\hline
\end{tabular}

Robust t-statistics reported in parentheses. ${ }^{* *}$ Significant at the 5 percent level.

2000-2007 ICELAND (Table 3): During this time period, investors from larger European countries, are more interested in investing in Iceland. European countries with smaller markets population are also more willing to invest. Investors from countries with highly skilled labour are more willing to invest. Investors from countries with different culture are less likely to invest in Iceland. Moreover, investors from countries not in EU are likely to invest. The effects on FDI from GDP source country economic size (GDP) are positive, but the effects from population negative, indicating that country wealth effects (GDP per capita) have positive effects on FDI, but not market size. EU membership of the source country has significant negative effects, indicating that it has hampering effects on outside investors if they have headquarters in an EU country, when seeking investments opportunities in Iceland. Skilled difference effects are positive, but cultural effects negative. The political and economic variables do not affect investment in this period, based on estimates.

2008-2010 ICELAND (Table 4): During this time period of 2000-2007, investors from European countries with high GDP per capita are more willing to invest, however dissimilarity in culture has negative effects. Additionally, EU membership of the country that the investor comes from has negative impact on their willingness to invest, although not significant. The most essential difference from the pre-crisis period in Iceland is that the source country membership to EU does not hold significantly back on foreign direct investment anymore, that is source country EU membership has negative impact, although insignificant impact on FDI. In other words, EU membership of the source country does not have hindering effects anymore. In addition, skilled labor difference does not have significant effects anymore. This indicated that the GDP, population and Hofstede cultural difference have the most impact in this time-period, since these are the significant variables. GDP and population of sources country have positive effect during this period while difference in culture has negative impact in FDI. 
2000-2007 IRELAND (Table 5): During this time period, the investors from European countries investing in Ireland are less willing to invest if indictors of credit and institutions in Ireland are higher up, other factors are not estimated to have significant effects on investors willingness. EU membership of the source country neither has stimulating nor hampering effects on FDI in Ireland, in 2008-2010. In addition, a notable feature is that credit is estimated to have significant negative effects, and risk of political instability to have significant negative effects.

2008-2010 IRELAND (Table 6): During this time period of 2000-2007, investors from European countries, investing in Ireland are less willing to invest if their country of origin has a smaller population, while they are more willing to invest in Ireland. The source country EU membership has significant positive effects on FDI in Ireland, during this period, unlike the preceding period. Thus, EU membership of source countries of investment does not hinder FDI, but rather stimulates FDI. The credit and instability measures do not have significant impacts anymore. However, source countries population size reflecting on market size is found to have significant negative effects.

\section{Summary and Conclusions}

The objective of this research was to analyze economic and political factors attracting foreign investors from European countries to either Ireland or Iceland, comparing the results before and after the financial economic crisis in 2008. Foreign direct investment (FDI) is an indicator of how interesting the country is in the eyes of potential investors, looking for long term investment opportunities, rather than portfolio investment. The countries for comparison are Iceland and Ireland, two islands with small economies. The model of choice is the gravity model, which has received international recognition and proven to be suitable for determining foreign direct investment. The gravity model accounts for economic size, market size, distance, culture, skilled labor, EU membership, country credit rating, investment risk, risk of political instability, and government efficiency. Instead of treating the data with the logarithm function when using the gravity model to take out the natural growth in the economic sizes, as is customary, the study uses the inverse hyperbolic sine function, when treating the model variables. This is a novel approach, which allows for accountancy of zeros, which can be important in the study of small economies. Moreover, since the sinh-1 procedure acts as robustness check for the conventional logarithm procedure, further robustness checks are not needed.

We based foreign direct investment (FDI) estimates for Ireland and Iceland on a set of explanatory variables. Findings indicate that before the 2008 crisis, EU membership did not make Ireland more attractive for FDI in the eyes of investors in other EU countries. However, EU membership made Ireland more attractive for FDI from other EU countries after the crisis. In comparison, Iceland was attractive to FDI from investors in non-EU countries, rather than EU countries, before the financial crisis. After 2008 the origin of investors within Europe had no significant effect on the flow of FDI into Iceland. Even though Iceland enjoyed a free flow of goods, capital, services and persons, through the EU and EFTA co-operation in the European Economic Area (EEA) - and despite the fact that the Icelandic krona was devalued after the crisis, Iceland still lagged behind Ireland in attracting more FDI. In other words, Iceland was still less attractive than Ireland as an investment option in the eyes of other European countries, after the crisis.

To sum up, in this study we used both economic and political variables to account for the complexities of FDI, both before and after the global financial crisis. This approach gives a clearer picture of the forces at play within the international economy that affect smaller economies. The results shed light on how trade bloc membership affects FDI within Europe. However, it has be kept in mind that the study did not include other parts of the world. In future research, it would be interesting to further expand the analysis, and take foreign direct investment from the United States, Asia, and other continents into account, as well as natural resources. 
Author Contributions: Conceptualization, H.K. and S.Ó.; methodology, H.K.; software, H.K. (Word, Excel, STATA); validation, H.K., S.Ó.; formal analysis, H.K. and S.Ó.; investigation, H.K. and S.Ó.; resources H.K.; data curation; writing - original draft preparation, H.K.; writing-review and editing, H.K. and S.Ó.; visualization, H.K. and S.Ó.; supervision H.K. and S.Ó.; project administration, H.K. and S.Ó.; funding acquisition, Not applicable since no funding received for this research. All authors have read and agreed to the published version of the manuscript.

Funding: This research received no external funding.

Institutional Review Board Statement: Not applicable.

Informed Consent Statement: Not applicable.

Data Availability Statement: Raw data can be made publicly available upon request.

Conflicts of Interest: The authors declare no conflict of interest.

\section{References}

Aðalsteinsson, Gylfi Dalmann, Svala Guðmundsdóttir, and Pórhallur Örn Guðlaugsson. 2011. Icelandic National Culture in Relation to Hofstede's Five Dimensions. Icelandic Review of Politics \& Administration 2: 353-68. [CrossRef]

Benediktsdóttir, Sigríður, Jón Danielsson, and Gylfi Zoega. 2011. Lessons from a collapse of a financial system. Economic Policy 26: 183-235. [CrossRef]

Bergstrand, Jeffrey. 1985. The gravity equation in international trade: Some microeconomic foundations and empirical evidence. The Review of Economics and Statistics 67: 474-81. [CrossRef]

Carr, David, James Markusen, and Keith Maskus. 2001. Estimating the knowledge-capital model of the multinational enterprise. American Economic Review 91: 693-708. [CrossRef]

Davies, Ronald. 2008. Hunting High and Low for Vertical FDI. Review of International Economics 16: 250-67. [CrossRef]

Davies, Ronald, and Helga Kristjánsdóttir. 2010. Fixed Costs, Foreign Direct Investment, and Gravity with Zeros. Review of International Economics 18: 47-62. [CrossRef]

Davies, Ronald, Delia Ionascu, and Helga Kristjánsdóttir. 2008. Estimating the Impact of Time-Invariant Variables on FDI with Fixed Effects. Review of World Economics 144: 381-407. [CrossRef]

ECB. 2020. European Central Bank. EU and Euro Area Membership. Available online: https:/ /www.ecb.europa.eu/stats/payments / paym/html/ data.en.html (accessed on 4 September 2020).

EFTA. 2020. European Free Trade Association. Available online: http:/ /www.efta.int (accessed on 10 September 2020).

European Union. 2020. Available online: https: / / europa.eu/ (accessed on 12 August 2020).

Gissurarson, Hannes. 2010. Why Iceland Does Not Want to Pay. The Wall Street Journal. Available online: https://www.wsj.com/ articles/SB10001424052748704842604574641913812666516 (accessed on 10 December 2020).

Guardian. 2015. Available online: https:/ /www.theguardian.com/world/2015/mar/12/iceland-drops-european-union-membershipbid (accessed on 10 December 2020).

Helpman, Elhanan. 1984. A simple theory of international trade with multinational corporations. Journal of Political Economy 92: 451-71. [CrossRef]

Hofstede, Geert. 1980. Culture's Consequences. New York: Sage.

Hofstede, Geert. 2001. Culture's Consequences: Comparing Values, Behaviors, Institutions, and Organizations across Nations. New York: Sage.

Hofstede, Geert, and Michael Harris Bond. 1988. The Confucius Connection: From Cultural Roots to Economic Growth. Organizational Dynamics 16: 4-21. [CrossRef]

IMD. 2020. Infrastructure; Lausanne: IMD International.

IMF. 2018. International Monetary Fund. Ragnarök: Iceland's Crisis, its Successful Stabilization Program, and the Role of the IMF. Poul M. Thomsen, Director, European Department, International Monetary Fund. Harpa Conference Center, Reykjavik. Available online: https://www.imf.org/en/News/Articles/2018/09/15/sp091518-ragnarok-iceland-s-crisis-its-successfulstabilization-program-and-the-role-of-the-imf (accessed on 10 September 2020).

IMF. 2020. International Monetary Fund. Available online: https://www.imf.org/en/Countries/ISL (accessed on 10 September 2020).

Keesing, Richard. 1998. The history of Newton's apple tree. Contemporary Physics 39: 377-91. [CrossRef]

Kristjánsdóttir, Helga. 2010. Foreign Direct Investment: The Knowledge-Capital Model and a Small Country Case. Scottish Journal of Political Economy 7: 591-614. [CrossRef]

Kristjánsdóttir, Helga. 2012. Exports from a Remote Developed Region: Analyzed by an Inverse Hyperbolic Sine Transformation of the Gravity Model. The World Economy 35: 953-66. [CrossRef]

Kristjánsdóttir, Helga. 2013. Foreign Direct Investment in a Small Open Economy. Applied Economics Letters 20: 1423-25. [CrossRef]

Kristjánsdóttir, Helga. 2016a. Foreign Direct Investment in the Hospitality Industry in Iceland and Norway in comparison to the Nordics and a range of other OECD countries. Scandinavian Journal of Hospitality and Tourism 16: 395-403. [CrossRef]

Kristjánsdóttir, Helga. 2016b. Can the Butler's tourist area cycle of evolution be applied to find the maximum tourism level? A comparison of Norway and Iceland to other OECD countries. Scandinavian Journal of Hospitality and Tourism 16: 61-75. [CrossRef] 
Kristjánsdóttir, Helga. 2017. Country Competitiveness: An Empirical Study. Baltic Region 9: 31-44. [CrossRef]

Kristjánsdóttir, Helga. 2019a. Tourism in a Remote Nordic Region: Vat, Internet, Oil, English, Distance, Hofstede, and Christianity. Cogent Social Sciences 5: 1709346. [CrossRef]

Kristjánsdóttir, Helga. 2019b. Does investment replace aid as countries become more developed? Baltic Journal of Economic Studies 5: 256-61. [CrossRef]

Kristjánsdóttir, Helga. 2020. Tax on tourism in Europe: Does higher value-added tax (VAT) impact tourism demand in Europe? Current Issues in Tourism. [CrossRef]

Kristjánsdóttir, Helga, and Sigríður Kristjánsdóttir. 2021. CarbFix and SulFix in geothermal production, and the Blue Lagoon in Iceland. Baltic Journal of Economic Studies 7: 1-20.

Kristjánsdóttir, Helga, and Stefanía Óskarsdóttir. 2020. EU-Country and Non-EU-Country at the Time of Crisis: Foreign Direct Investment. Baltic Journal of Economic Studies 6: 19-23. [CrossRef]

Kristjánsdóttir, Helga, Pórhallur Örn Guðlaugsson, Svala Guðmundsdóttir, and Gylfi Dalmann Aðalsteinsson. 2017. Hofstede National Culture and International Trade. Applied Economics 49: 5792-801. [CrossRef]

Kristjánsdóttir, Helga, Pórhallur Örn Guðlaugsson, Svala Guðmundsdóttir, and Gylfi Dalmann Aðalsteinsson. 2020. Cultural and geographical distance: Effects on UK exports. Applied Economics Letters 27: 275-79. [CrossRef]

Krugman, Paul. 1991. Increasing Returns and Economic Geography. The Journal of Political Economy 99: 483-99. [CrossRef]

Krugman, Paul. 2011. A Song of Ice and Ire: Iceland in Context. Presentation at the IMF Conference Iceland's Recovery-Lessons and Challenges, Reykjavik, Iceland. Available online: http://www.imf.org/external/np/seminars/eng/2011/isl/ (accessed on 8 January 2020).

Markusen, James. 1984. Multinationals, multi-plant economies, and the gains from trade. Journal of International Economics 16: 205-26. [CrossRef]

Markusen, James, Anthony Venables, Denise Eby-Konan, and Kevin Zhang. 1996. A Unified Treatment of Horizontal Direct Investment, Vertical Direct Investment, and the Pattern of Trade in Goods and Services. Working Paper No. 5696. Cambridge: NBER.

Markusen, James. 2004. Multinational Firms and the Theory of International Trade. Cambridge: MIT Press.

OECD. 2020. FDI Series of BOP and IIP Aggregates. Inward Position at Year-End. Available online: http://stats.oecd.org/Index.aspx? DataSetCode=FDI_FLOW_PARTNER\# (accessed on 2 January 2020).

Óskarsdóttir, Stefanía. 2013. People versus politicians: The political aftermath of the financial crisis in Iceland. Open Citizenship 4: 34-45.

Pöyhönen, Peniti. 1963. A Tentative Model for the Volume of Trade between Countries. Weltwirtschaftliches Archiv 90: 93-100.

Riain, Seán. 2012. The crisis of financialisation in Ireland. The Economic and Social Review 43: 497-533.

Tinbergen, Jan. 1962. Shaping the World Economy: Suggestions for an International Economic Policy. New York: The Twentieth Century Fund.

Thorhallsson, Baldur, and Christian Rebhan. 2011. Iceland's economic crash and integration takeoff: An end to European Union scepticism? Scandinavian Political Studies 34: 53-73. [CrossRef]

World Bank. 2020. Data. Available online: http:/ / data.worldbank.org/indicator (accessed on 1 February 2020).

Zwinkels, Remco, and Sjoerd Beugelsdijk. 2010. Gravity equations: Workhorse or Trojan horse in explaining trade and FDI patterns across time and space? International Business Review 1: 102-15. [CrossRef] 